\title{
Professional identity for successful adaptation of students - a participative approach
}

\author{
Galina Akhmetovna Gertsog, ${ }^{1}$ Viktoriya Valerievna Danilova, ${ }^{2}$ Dmitry \\ Nikolayevich Korneev, ${ }^{3}$ Aleksey Viktorovich Savchenkov, ${ }^{4}$ Nataliya \\ Viktorovna Uvarina ${ }^{5}$ \\ 1,3, 4,5 Southern Ural state Humanitarian and Pedagogical University, Chelyabinsk, the \\ Russian Federation \\ ${ }^{2}$ Kostanay State Pedagogical Institute, Kazakhstan.Email: nuvarina@yandex.ru
}

Received February 10, 2017; Revised April 16, 2017; Accepted April 27, 2017; Published May 5, 2017.

\begin{abstract}
It is stated that in the Russian Federation, Kazakhstan as well as throughout the world the crisis of personal identity has become a big problem due to globalization in the society and multifaceted participation of people in social processes. The article deals with the analysis of the concept of professional identity of the student on the basis of participative approach. Professional identity is viewed as the main criterion and result of the student's successful adaption to the learning environment, professional and creative activities as well as to changing social and cultural conditions. The authors advocate for the proposition that the professional identity being the element of social and cultural identity allows students to overcome the state of anxiety, lack of confidence, tension, and dissatisfaction presenting the obstacles to the process of adaption to the changing conditions in the globalised world. The authors assume that the study of the stated phenomenon of professional identification on the theoretical and empirical levels will allow implementing innovational technologies of coherent cooperation of social and cultural environment of the higher educational institution having impact on the professional growth of students. Professional identity is presented within the framework of both individuality and group.
\end{abstract}

Key words: adaptation, participation, globalization, identity, professional identity, socialization, transformation.

\section{Introduction}

The choice of the topic of the research has been determined by the following reasons: necessity of transformation of professional adaptation of students into the basis for their further professional development and self-development and the existence of crisis of identity of the modern person in globalised world.

The problem of professional identity has been studied over centuries by local and foreign researchers. Many researchers state that modern globalised world is changing more intensively than the person and his consciousness itself. The researchers in the field of overall and vocational identity (Sestito et al., 2015) mainly use person-centered approach applied to identity domain (Crocetti, Rubini, Luyckx, \& Meeus, 2008). In our research, we use the participative approach as the approach to present the performance of the student as being involved into the system of relations (Danilova, 2015) to indicate the process of overlapping of identity, personal activity and the globalised world.

(c) AesthetixMS 2016. This Open Access article is published under a Creative Commons Attribution Non-Commercial 4.0 International License (http://creativecommons.org/licenses/by-nc/4.o/), which permits non-commercial re-use, distribution, and reproduction in any medium, provided the original work is properly cited. For citation use the DOI. For commercial re-use, please contact editor@rupkatha.com. 
A person being under the pressure of the time "is urged to search for his identity with the help of some magic tool leading to the 'higher' state of consciousness” (Toffler, 1989).

Nowadays the crisis of individual and collective identities has been noted as congruent in recent scientific works. The 'identity being diffused' (Stepin, 2007) or polyidentity have become the key characteristics of modern identity. According to the research by Stepin, he consciousness of people in modern world has acquired the attribute of fragmentarity resulting in ambiguous self-perception of the people.

The dynamics of civilized processes, destruction of norms and values peculiar to the country, diversification of the processes of integration of past and future as well as various communication flows led to demarcation of social interconnections on the individual and collective levels.

Recent studies illustrate that the term 'professional identity is a frequently used one in teacher education although there is little consensus of what it means for practice' (Mentis et al, 2016). On the one hand, the person is experiencing difficulty when giving an answer to the question on his professional identity because of his weak perception of himself as a person, in general. Therefore, it is possible to assume that the identity issue is rooted in both vital and professional ideology. On the other hand, supporting the view of M. Gorshkov and N. Sedova, we agree upon the fact that the person facing with vital events is forced to take the responsibility for his own decisions resulting in the core asset defining the level of success gained from the realization of the vital goals (Gorshkov, Sedova, 2015). The level of adaptability to the changing social norms and values correlates with process of forming the identity. Thus, participation as a key factor of forming identity has been identified as a theoretical basis for this research.

\section{Methodology}

Identification of the core of the problem of identity as well as its structure, genesis and formation conditions are considered the central objectives of the education owing not only to the mentioned above crisis of identity (as a certain form of professional estrangement induced by the social character of labour - (Schneider, 200o), but also to the prominent objectives in the field of education of the person and his development, self-actualization and spirituality.

This idea was embodied in the array of studies, both local and foreign (G. Andreyeva, T. Buyakas, A.Kuzmin, D. Orlov, M. Putilova, A. Lukyanov, P. Gurevich, A. Toffler).

The term 'identity' is defined as 'approximation', 'uniformity', 'similarity'(Dictionary of foreign words, 1996). This definition has relatively broad and fuzzy interpretation. Dealing with the identity of the person, it must be assumed that this notion has the complex structure embracing diverse states of the person, various levels of consciousness (individual and collective) and ontogenetic and sociogenetic bases in consequence of which the person recognizes himself as a part of the human world, professional sphere, national identification, etc. That is to say, identity is the complex phenomenon characterizing the congruity of the 'Self-image' to its vital embodiment in various everyday spheres. Referring to the philosophic views dated back centuries ago (Socrates, Plato, Hegel, I. Kant, L. Lévy-Bruhl, M. Mid, E. Fromm, M. Foucault, M. Bakhtin, F. Dostoevsky, etc.) 'the identity' is treated as unicity of the nature and singularity of the personality being the result of his reflection over the human history, universal and individual values interiorized by him in the process of formation. In other words, identity is the outcome of the internal self-realisation of the person when exposed to the external vital context. Consequently, 
the issue on the professional identity and identification ought to be placed into the angle of the professional development, self-evolution and self-realisation.

However, the problem of professional identity being crucial leaves many unsolved and explicit issues. The analysis of scientific resources cannot provide us with the distinct and unambiguous definition of the professional identity, its sense and nature, origin in the framework of personality development, to mention few.

In the given paper we advocate for the two main approaches to professional identity. The first one represents the ways of revelation of the factors significant to the personality viewed by the society (having both positive and distracting impact). The second approach is based on the perspective of the personality reflected in the society. Being exposed to various emotional evaluations, the person can experience negative states as indifference, resentment, fear, distrust, phobia, exasperation. Nevertheless, personal feelings can be relatively stable in terms of optimism and trust when tackling the problem in a collaborative, participative way sustaining the 'emotional balance in constantly altering social environment' (Levada, 2003).

The role of education from the lens of the teacher training programmes was estimated by the scholars Ivanova, Shara-Mincanea, who claim that 'during teaching practice, not only professional, but also personal development takes place'. This supposition rationalizes the participative approach as the theoretical foundation for the research carried out (Ivanova, SharaMincanea, 2016).

The necessity to analyse the concept of professional identity from theoretical and empirical angles is determined by insufficient study of the identities crisis of the person in modern world. Instability of the changing worlds and crisis of identities overlap and intersect each other in the field of our research.

Having mentioned the aim of our research, we emphasize the idea of reorganization of the educational process so that the student can demonstrate the practical readiness for the professional sphere as well as for social adaptation to the rapidly changing globalised world. Brief overview of theoretical resources on the topic of the research enabled us to formulate the work definition of the notions 'professional identity' and 'sociocultural identity'.

Professional identity is perceived by us as the state of the person determined by his reflection with regard to his place in the professional sphere, his aptitudes and abilities, drives for professional values providing the holistic approximation and certainty in the professional activity. Having the immanent and integral character inherent in the personality, identity is formed in the process of professional identification. In its turn, professional identification may be considered from two perspectives: as the process and as the result. In this research dedicated to the field of teacher training, we agree with the opinion of Beijaard, Meijer, \& Verloop (2004) who state that "professional identity as an ongoing process of integration of the 'personal' and the 'professional' sides of becoming and being a teacher.'

Sociocultural identification of students is viewed as a complex influence on the social, cultural, and professional and ethical qualities of the personality of future teachers.

The need to clarify the notions was determined by the assumption that professional identity of the student is formed and progressed in the framework of soiciocultural environment of the higher educational institution.

Researching process of professional identification of students of higher educational institution, we proceeded from the general provision which is the cornerstone of a definition of 
the concept "professional identification" (see above). From here the following markers characterizing professional identity are structurally allocated:

- World outlook based component - ideas of respondents on professional values, personal drives on implementation of these values into own activity.

- Cognition based component - knowledge providing process of professional development and self-development.

- Activity based component - the competences allowing performing professional functions effectively, providing professional mobility.

Besides that, a number of factors which influence was studied in the empirical research conducted by us have been identified.

These factors include:

- an opportunity to self-realization in the profession;

- conditions for development of professional requirements, interests, claims;

- prestige of a profession and an opportunity to apply a relevant qualification received in higher educational institution.

Certainly, the influence of factors on professional identification is more significant than it has been listed above. But the purpose of our research was to scrutinize the influence of the mentioned above factors.

\section{Base for the Empirical research}

The research was conducted on the basis of questionnaire of students (bachelors), students at Professional Teacher Training Institute of the Southern Ural State Humanitarian and Pedagogical University on the specialty: "Professional training" ("Arts, crafts and design"; "Informatics and computer facilities"; "Transport"; "Jurisprudence and law-enforcement activities", "Economy and management", "Food production", etc.). Training of teachers in accord with the specialties enumerated above is performed for providing the professional educational organizations in Chelyabinsk region with the qualified teaching staff realizing content of special and general technical disciplines included in the standard of education.

Qualification of such profile of teaching staff has a binary character. On the one hand, the teacher of this profile has to have the professional competences required, on the other hand, he becomes the source of professional knowledge and that is especially important, the owner of technical and creative professionally important abilities of the specialist of the specific field. This feature of qualification staticizes a research on professional identity (disclosure of its structure, genesis, dynamics, and also definition of conditions of its formation and practical realization during vocational training). The analysis of publications and dissertations shows that studies in the field of professional identification of teachers of vocational education were very few in number. At the same time, binarity of the profession of such a profile has the peculiar impact both on the essence of the concept of professional identity and the process of identification of the students studying on the aforesaid specialties. 


\section{Methods of the research: questionnaire}

As we have already mentioned, the empirical research was conducted by a method based on questionnaire. The questionnaire was elaborated on the basis of the methodological section of the program of a research and constructed of units (clusters) reflecting components of the structure of professional identity. 572 respondents participated in the questionnaire ( $131-$ students of the $1^{\text {st }}$ course and 441 students of the $4^{\text {th }}$ courses). The survey conducted was of the continuous type (continuous selection, 100\%).

\section{Results of the empirical research:}

In the structure of the professional identity (see above) components to be directly measured and analyzed have been allocated. The world outlook based component was studied by the block of the questions characterizing ideas of respondents on professional values, personal drives on implementation of these values into their own activity and the importance of a profession in society.

The empirical data characterizing a world outlook based component of professional identity of students of the mentioned institution are presented in the Tables 1, 2, 3 in dynamics.

Table1

Ideas of respondents on the importance of the specialty (profession) acquired by them for social development (in per cent)

\begin{tabular}{|l|l|l|l|}
\hline$\#$ & Significance value of a profession for the society & $\begin{array}{l}\text { Students of } \\
\text { the } 1^{\text {st }} \\
\text { course } \\
(131)\end{array}$ & $\begin{array}{l}\text { Students of } \\
\text { the } \\
\text { course } \\
(44)\end{array}$ \\
\hline 1 & $\begin{array}{l}\text { It is very important and necessary, has a great influence on } \\
\text { development of society and its economy, culture }\end{array}$ & 7.6 & 51.7 \\
\hline 2 & $\begin{array}{l}\text { It is necessary to society, but does not have a great influence } \\
\text { on social life }\end{array}$ & 60.3 & 37.5 \\
\hline 3 & $\begin{array}{l}\text { It is necessary to society, but it does not influence its } \\
\text { economic and cultural condition }\end{array}$ & 21.4 & 3.8 \\
\hline 4 & I find it difficult to answer & 10.7 & 1.6 \\
\hline & Total: & 100.0 & 100.0 \\
\hline
\end{tabular}

As it is seen from the comparison of empirical data (see Table 1) the results of answers of university graduates (students of the 4th course) estimate the importance of the profession acquired by them for society in a more adequate way. It is possible to assume that the educational trajectory they took, in greater extend, as well as the professional experience gained from the preservice practice, have considerably influenced the process of their professional identification. 
Assessment of the importance of professional values differs at students of the ist and 4 th courses. First-year students give a priority to such values as knowledge, positive assessment of results of work issued by the social subjects (pupils, heads, colleagues, society in general), while university graduates (the $4^{\text {th }}$ course) give the importance to such professional values as career, adequate compensation, competence and respect by criterion of "professionalism", the integrated knowledge and abilities, creative nature of work. At the same time knowledge providing process of professional development and self-development as the value and a cognitive component of professional identity with the vast majority of students of both $1^{\text {st }}$ and $4^{\text {th }}$ courses are highly appreciated.

However, some discrepancies in assessment of the importance of knowledge as values have been observed in the answers of students of the $1^{\text {st }}$ course. In structure of values, they give a highest consideration to the knowledge, $93.8 \%$ of respondents specify it (see Table 2 ). At the same time, only $58.7 \%$ out of them note that the wide range of professional knowledge is important for them personally, and they are going to reach them (see: Table 3). From this it is necessary to assume that the real importance of knowledge is not considered as something very important by students of the ist course, which will complicate the process of professional identification. It is necessary to pay attention to such a fact that most of the students of the 4 th course realized the need for acquisition of a wide range of professionally important knowledge, enhancement of professional competences. The priorities ranged by students demonstrate that the gained working and social experience in higher educational institution influences revaluation of values of graduates (students of the 4 th course).

It is also possible to assume that the sociocultural environment of higher educational institution determined by interaction and cooperation of all subjects of educational process in the sphere of their joint educational and cultural activities exerted positive impact on dynamics of world outlook drives and values of the students of the $4^{\text {th }}$ course, thereby promoted forming the professional identity of the student.

Table 2

Evaluation of the importance of professional values as sociocultural phenomenon by respondents. (Respondents were offered to choose several most important professional values from their point of view)

\begin{tabular}{|c|c|c|c|c|c|}
\hline \multirow[t]{2}{*}{ \# } & \multirow[t]{2}{*}{ The content of professional values } & \multicolumn{2}{|c|}{$\begin{array}{l}\begin{array}{l}\text { Students of } \\
\text { the }\end{array} \\
\text { course } \\
(131)\end{array}$} & \multicolumn{2}{|c|}{$\begin{array}{l}\text { Students of } \\
\text { the } 4^{\text {th }} \text { course } \\
(441)\end{array}$} \\
\hline & & $\%$ & Range & $\%$ & Range \\
\hline 1 & Career as a value (opportunity of career growth) & 66.4 & 5 & 86.6 & 2 \\
\hline 2 & Adequate salary & 87.0 & 2 & 100.0 & 1 \\
\hline 3 & $\begin{array}{l}\text { High evaluation of the profession from the side of society } \\
\text { (prestige of the profession) }\end{array}$ & $84 \cdot 7$ & 3 & 86.6 & 2 \\
\hline
\end{tabular}




\begin{tabular}{|c|c|c|c|c|c|}
\hline 4 & Devotion to the profession & 60.3 & 7 & 51.7 & 6 \\
\hline 5 & $\begin{array}{l}\text { Having abilities, aptitudes, skills to perform the given } \\
\text { professional activity }\end{array}$ & $63 \cdot 3$ & 6 & 86.6 & 2 \\
\hline 6 & Respect and professionalism & 72.5 & 4 & 86.6 & 2 \\
\hline 7 & $\begin{array}{l}\text { Opportunity to establish professional communication in } \\
\text { the teaching staff }\end{array}$ & 58.7 & 8 & 73.2 & 5 \\
\hline 8 & Opportunity to build professional bonds & 58.7 & 8 & 73.2 & 5 \\
\hline 9 & Opportunity to self-realize in the profession & 60.3 & 7 & 84.1 & 4 \\
\hline 10 & $\begin{array}{l}\text { Positive evaluation of the results of the work coming } \\
\text { from the teacher/lecturer }\end{array}$ & 93.8 & 1 & 39.0 & 7 \\
\hline 11 & $\begin{array}{l}\text { Positive (adequate) evaluation of the results of work } \\
\text { coming from the peers/teaching staff }\end{array}$ & 93.8 & 1 & 73.2 & 5 \\
\hline 12 & $\begin{array}{l}\text { Positive (adequate) evaluation of the results of work } \\
\text { coming from the administration }\end{array}$ & 93.8 & 1 & 73.2 & 5 \\
\hline 13 & Deep and profound professional knowledge & 93.8 & 1 & $85 \cdot 9$ & 3 \\
\hline 14 & Integrative professional skills & $63 \cdot 3$ & 6 & $85 \cdot 9$ & 3 \\
\hline 15 & Creative character of the work & $63 \cdot 3$ & 6 & $85 \cdot 9$ & 3 \\
\hline
\end{tabular}

Table 3

Personal drives on implementation of the domineering professional values in their own activity (in per cent)

\begin{tabular}{|c|c|c|c|c|c|}
\hline \multirow[t]{2}{*}{ \# } & \multirow[t]{2}{*}{ The content of professional values } & \multicolumn{2}{|c|}{$\begin{array}{l}\text { Students of the } 1^{\text {st }} \\
\text { course } \\
(131)\end{array}$} & \multicolumn{2}{|c|}{$\begin{array}{l}\text { Students of the } 4^{\text {th }} \\
\text { course } \\
(441)\end{array}$} \\
\hline & & $\begin{array}{l}\text { Having } \\
\text { personal } \\
\text { meaning }\end{array}$ & $\begin{array}{l}\text { Having } \\
\text { no } \\
\text { personal } \\
\text { meaning }\end{array}$ & $\begin{array}{l}\text { Having } \\
\text { personal } \\
\text { meaning }\end{array}$ & $\begin{array}{l}\text { Having } \\
\text { no } \\
\text { personal } \\
\text { meaning }\end{array}$ \\
\hline 1 & Deep and profound professional knowledge & 58.7 & 41.1 & 84.1 & $15 \cdot 9$ \\
\hline 2 & Professional competence & 58.7 & 41.1 & 84.1 & $15 \cdot 9$ \\
\hline
\end{tabular}




\begin{tabular}{|l|l|l|l|l|l|}
\hline 3 & $\begin{array}{l}\text { Positive evaluation of the results of the work } \\
\text { from the } \\
\text { coming } \\
\text { society/teacher/lecturer/peer/administration }\end{array}$ & 43.5 & 56.5 & 84.1 & 15.9 \\
\hline 4 & Opportunity to self-realize in the profession & 20.6 & 79.4 & 84.1 & 15.9 \\
\hline 5 & Respect and professionalism & 63.3 & 36.7 & 84.1 & 15.9 \\
\hline 6 & $\begin{array}{l}\text { Opportunity to build professional bonds } \\
77\end{array}$ & $\begin{array}{l}\text { Opportunity to establish professional } \\
\text { communication in the teaching staff, } \\
\text { professional community }\end{array}$ & 71.0 & 64.2 & 35.8 \\
\hline
\end{tabular}

The sociocultural environment of higher educational institution is marked not only by communicative bonds and interrelations, but also includes norms, rules, traditions, types of activity, etc. One of the problems of our research was the analysis of professional requirements and claims of the respondents defining an activity based component of the professional identity. The empirical data characterizing claims and needs of students of participation in different types of activity are presented in Table 4.

Table 4

The characteristics of professional claims and needs of respondents during the study and after graduation from the higher educational institution

(in the \%)

Remark: Students could chose more than one option out of the offered ones

\begin{tabular}{|c|c|c|c|}
\hline \# & In the process of study I would like to: & $\begin{array}{l}\text { Students } \\
\text { of the } 1^{\text {st }} \\
\text { course } \\
(131)\end{array}$ & $\begin{array}{l}\text { Students } \\
\text { of the } 4^{\text {th }} \\
\text { course } \\
(441)\end{array}$ \\
\hline 1 & $\begin{array}{l}\text { Take part in scientific and research activity in the field of my } \\
\text { profession }\end{array}$ & 12.9 & 61.7 \\
\hline 2 & $\begin{array}{l}\text { Take part in scientific and research activity in the field of my } \\
\text { interest }\end{array}$ & 43.5 & 1.6 \\
\hline 3 & $\begin{array}{l}\text { Have an opportunity to participate in conferences, workshops at } \\
\text { various levels }\end{array}$ & 20.6 & 61.7 \\
\hline 4 & $\begin{array}{l}\text { Have an opportunity to participate in competitions for } \\
\text { funding/awarding grants for study }\end{array}$ & 12.9 & 27.4 \\
\hline 5 & Have an opportunity to participate in the competitions of the & $33 \cdot 5$ & 39.0 \\
\hline
\end{tabular}




\begin{tabular}{|c|c|c|c|}
\hline & professional character, creative projects & & \\
\hline 6 & Have an opportunity to participate in the inventive activity & $5 \cdot 3$ & 16.3 \\
\hline 7 & $\begin{array}{l}\text { Have an opportunity to attend extra-curricular activities for joint } \\
\text { professions }\end{array}$ & $33 \cdot 5$ & 16.3 \\
\hline 8 & $\begin{array}{l}\text { Have an opportunity to have a part-time job officially (gain the } \\
\text { professional experience) }\end{array}$ & 45.8 & 84.1 \\
\hline 9 & $\begin{array}{l}\text { Have an opportunity to be hired in the educational institution } \\
\text { after graduation }\end{array}$ & $47 \cdot 3$ & $27 \cdot 4$ \\
\hline 10 & $\begin{array}{l}\text { Have an opportunity to be hired in the educational institution } \\
\text { after graduation in the branch-related spheres }\end{array}$ & $33 \cdot 5$ & 72.6 \\
\hline 11 & $\begin{array}{l}\text { Have an opportunity to get the position in accordance with the } \\
\text { level of education }\end{array}$ & 93.8 & 86.8 \\
\hline 12 & I have never thought of these issues & 19.2 & 1.6 \\
\hline
\end{tabular}

Judging by a percentage ratio of students of the $1^{\text {st }}$ and $4^{\text {th }}$ courses at the choice and definition of the importance of the types of activities characterizing an activity based component of professional identity it is possible to emphasize a considerable difference in some parameters. For example, motives of students of the $1^{\text {st }}$ and the $4^{\text {th }}$ courses in the area of study and research activity significantly differ. Unlike the first-year students who are focused on studying of the problems connected with their personal interest, the students of the $4^{\text {th }}$ courses intend to participate in the research on the problems connected with their profession. The difference of motives and claims of students at the choice of the types of activity characterizing an activity based component of professional identity is also visible by other parameters.

The fact that students of the 4th course obtain a rather definitely determined intentions in the sphere of their future profession by the end of study attracts our attention. So, $72.6 \%$ of the students intend to work in the field of their professional sphere. Among the factors which influenced professional self-determination of graduates in their branch-related specialties the following ones can be allocated: initial motive to build professional career in the professional sphere, transitive (temporary) work in the sphere, interest in the study of branch-related disciplines (objects) during study and own efforts directed to acquiring knowledge and skills in the field of training, good organization of technological practice, creative nature of work, an opportunity to participate in creative competitions and the movement "World Skills", an opportunity to find a job in the chosen branch of industry, etc. It is possible to conclude that the sociocultural environment of higher educational institution gave the students more opportunities to realize the professional identification in the field of the industry based sphere of specialty.

One of the most important factors determining the choice of students of the $4^{\text {th }}$ course in the industry based branches of specialty is their position of the teaching profession as the lowpaid and having a little prestige. 32,0 \% of the respondents indicated this factor. Certainly, the material component among factors of satisfaction with the work performed has a paramount importance. 


\section{Conclusion and research findings}

Some key results of the study of a problem of professional identity of the students undergoing the system of binary specialty called "The Teacher of Vocational Education" are presented in the article.

In the given research, the assumption was made that study of professional identity of the student will allow revealing influence of the sociocultural environment of higher educational institution on the process of professional identification.

The research findings include the following aspects:

- The structure of professional identity has a participative character and includes world outlook based component, cognition based component, and activity based component. The interconnection between these components is realized through the soiciocultural environment gained by the students via the scope of disciplines of professional cycle in HEIs.

- The identified factors on the empirical level of the research include objective and subjective ones. Objective factors are presented by the norms, rules and regulations, traditions and forms of organization of students in social environment of the higher educational institution. Subjective factors encompass the claims of students on social significance of the teaching profession, professional values, motives and interiorisation of knowledge and skills. The more the student is involved into the professional sphere, the more subjectivity characterizes his adaption.

Our research bears the applied character and does not claim for universalization. Its purpose is to include a problem of training of a pedagogical staff on binary nature in a scientific discourse. This problem has been urgent since the regional labor markets have a vast deficiency in teachers of professional training.

The perspectives of the work can include the revealing of the aspects of participation of students during the process of interiorisation of social values; cross-cultural research in the field of professional adaption of students during their pre-service practice.

\section{References.}

Beijaard, D., Meijer, P. C., \& Verloop, N. (2004). Reconsidering Research on Teachers' Professional Identity. Teaching and Teacher Education, 20, P.107-128.

Crocetti, E., Rubini, M., Luyckx, K., \& Meeus, W. (2008). Identity formation in early and middle adolescents from various ethnic groups: From three dimensions to five statuses. Journal of Youth and Adolescence, 37, P. 983-996.

Danilova, V.V. (2015). Forming participative readiness of teacher trainees for the upbringing activity // Thesis dissertation on candidate of pedagogical sciences / V.V. Danilova, Chelyabinsk, 2015. - 235 p.

Gnatyshina, E.A. (2015). Training of teachers of vocational education in the conditions of competence focused management of educational process of higher educational institution / E.A. Gnatyshina, G. A. Gertsog // Professional education: methodology, technologies, practice [Text]: the collection of scientific articles / under the editorship of V.V. Sadyrin. - Chelyabinsk: CJSC "Tsitsero publishing house", CSPU, 2015. Vol 8. - 244 p.

Gorshkov, M.K. (2015). "Self-sufficient" Russians and their life priorities /M.K. Gorshkov, N.N. Sedova // Sotsis, 2015. - No. 12. - P. 4-16. 
Ivanova, I., Skara-Mincanea, R. (2016). Development of Professional Identity during Teacher's Practice / International Conference on Teaching and Learning English as an Additional Language, GlobELT, 2016, 14-17 April 2016, Antalya, Turkey // Procedia - Social and Behavioral Sciences 232 (2016), P. 529 - 536.

Levada, Yu.A.(2003). From opinions to understanding. Sociological sketches. 1993-2000. M.: The Moscow school of polit. researches, 2003.-576 p.

Mentis, M., Holley-Boen, W., Butler, Ph., Kearney, A., Budd, J., Riley, T., MacArthur, J., Dharan, V., BevanBrown, J. (2016) / Māwhai: Webbing a professional identity through networked interprofessional communities of practice // Teaching and Teacher Education, Volume 6o, November 2016, P. 66-75.

Schneider L.B. (200o). Experimental study on professional identity - M.; LLC Print, 200o. - 128 p. [Available at: http://psychlib.ru/mgppu/shn/SHN-oo1-.HTM]

Sestito, L.A., Sica, L.S., Ragozini, G., Porfeli E., Weisblat G., Palma, T.D. (2015). Vocational and overall identity: A person-centered approach in Italian university students // Journal of Vocational Behavior, Vol. 91, December 2015, P. 157-169.

Stepin, V.S. (2007). Russia in the globalizing world: worldview and socio-cultural aspects. Moscow: Russian Academy of Sciences, 2007. - $640 \mathrm{p}$.

The dictionary of foreign words (1996) / Under the editorship of I.V. Lekhin, F.N. Petrov. - M.: YuNVES, 1996. $-832 \mathrm{p}$.

Toffler A. (1989) The third wave, Bantam Books,1989. - 537 p.

Galina Akhmetovna Gertsog, Candidate of philosophical sciences, The head of the scientific and research department Professional and Pedagogical Institute of Southern Ural state humanitarian and pedagogical University, Postal address: 45400o, 37 flat no.,15 Lenin str., Chelyabinsk, the Russian Federation.

Viktoriya Valerievna Danilova, Candidate of pedagogical sciences, Master of pedagogy and psychology, senior teacher of English, department of Foreign Languages, Kostanay State Pedagogical Institute, Postal address: 110003, 284 flat no., 39 Temirbaev str., Kostanay, Kazakhstan.

Dmitry Nikolayevich Korneev, Candidate of pedagogical sciences, docent, Docent of the Philology Department of Economy, Management and Law Southern Ural state humanitarian and pedagogical University, Postal address: 454128, 63 flat no., 16/a Street after 250-anniversary of Chelyabinsk Chelyabinsk, the Russian Federation..

Aleksey Viktorovich Savchenkov, Candidate of pedagogical sciences, Docent of the Department of training of professional education teachers and subject based methods, Southern Ural state humanitarian and pedagogical University, Postal address: 454084, 28 flat no., 97 a Kaslinsk str., Chelyabinsk, the Russian Federation.

Nataliya Viktorovna Uvarina, Doctor of pedagogical sciences, professor, department of teacher training for professional education and specialized methods, Southern Ural state humanitarian and pedagogical University, Chelyabinsk, the Russian Federation, Postal address: 45400o, 86 flat no., 3, Krasnoznamennaya str., Chelyabinsk, the Russian Federation. 